\title{
Escape From Interlabial Space or Lateral Juncture; No Extension
}

National Cancer Institute

\section{Source}

National Cancer Institute. Escape From Interlabial Space or Lateral Juncture; No

Extension. NCI Thesaurus. Code C127185.

A finding of escape from interlabial space or lateral juncture during swallowing, but no extension. 